\title{
Pengaruh Film "Jembatan Pensil" Terhadap Altruisme Siswa Dasar (Studi pada Siswa SD Muhammadiyah 10 Balongbendo)
}

\author{
Ria Ayu Cahyaning Pratiwi ${ }^{1}$, Sayidah Auliaul Haque ${ }^{2}$ \\ ${ }^{1}$ Magister Psikologi, Fakultas Psikologi Universitas 17 Agustus 1945, \\ ${ }^{2}$ Fakultas Psikologi Universitas 17 Agustus 1945 \\ Email: ${ }^{1}$ riaayu_s2@untag-sby.ac.id, ${ }^{2}$ aulia.sby@gmail.com
}

\begin{abstract}
Abstrak
Altruisme adalah tindakan sukarela yang dilakukan oleh seseorang atau sekelompok orang untuk menolong orang lain tanpa mengharapkan imbalan apapun (kecuali mungkin perasaan telah melakukan kebaikan) (Sears dkk, 1994). Tujuan dari penelitian adalah untuk mengetahui sikap altruisme yang dimiliki oleh siswa sekolah dasar dalam perilaku keseharian di lingkungan sekolah, mengingat anak-anak di era sekarang sangat minim rasa tolong-menolong terhadap temannya. Penelitian tentang ini penting dilakukan mengingat sikap individualis dan bullying yang makin marak di kalangan anak SD. Penelitian ini menggunakan metode kuantitatif dalam bentuk kuasi eksperimen dengan desain Nonequivalent Control Group Design. Hasil temuan menunjukkan bahwa : 1) Tidak ada perbedaan yang signifikan hasil altruism siswa antara kelas yang menggunakan dan tidak menggunakan media pembelajaran film Jembatan Pensil sebelum perlakuan, 2) Ada perbedaan hasil altruism siswa di kelas yang tidak menggunakan media pembelajaran film Jembatan Pensil sebelum dan sesudah perlakuan, 3) Ada perbedaan hasil altruisme siswa di kelas yang menggunakan media pembelajaran film Jembatan Pensil sebelum dan sesudah perlakuan, 4) Ada perbedaan yang signifikan hasil altruism siswa antara kelas yang menggunakan dan tidak menggunakan media pembelajaran film Jembatan Pensil setelah perlakuan.
\end{abstract}

Kata kunci : Altruisme, Film, Siswa Sekolah Dasar

\section{Pendahuluan}

Manusia merupakan makhluk sosial yang diciptakan untuk berdampingan dengan orang lain dan tidak bias hidup secara individual. Sebagai makhluk social hendaknya manusia saling tolong menolong satu sama lain dan mengadakan interaksi dengan orang lain untuk bertukar pikiran serta untuk memenuhi kebutuhan hidupnya. Hal ini sering terlihat secara langsung dalam masyarakat, seperti kegiatan sambatan, kerja bakti, atau memberi bantuan baik berupa barang maupun jasa pada orang yang sangat membutuhkan. Memberikan bantuan ataupun 
PSISULA: Prosiding Berkala Psikologi

Vol. 1, 2019

E-ISSN: 2715-002X

keuntungan pada orang lain tanpa mengharap imbalan apapun dalam psikologi disebut dengan altruisme.

Ada juga sebagian orang yang mau memberikan pertolongan dengan mempertimbangkan motif dalam diri si penolong, misalnya untuk mengharapkan imbalan dari orang yang telah ditolong. Wahyuningsih (Setyawan, 2010) menyatakan penggunaan berbagai technologi canggih yang tampak memberikan kemudahan bagi kehidupan manusia pada kenyataannya menimbulkan dampak negative bagi pola hidup dan tingkah laku social manusia.

Tujuan dari penelitian ini adalah untuk mengetahui sikap altruisme yang dimiliki oleh siswa sekolah dasar dalam perilaku keseharian di lingkungan sekolah, mengingat anak-anak di era sekarang sangat minim rasa tolong-menolong terhadap temannya. Penelitian tentang ini penting dilakukan mengingat sikap individualis dan bullying yang makin marak di kalangan anak SD.

Masalah yang dirumuskan dalam penelitian ini adalah : 1) Masih kurangnya pemahaman tentang perilaku altruism pada siswa SD. 2) Metode yang digunakan oleh guru kurang tepat dalam hal menanamkan perilaku altruism pada siswa di sekolah sehingga perilaku altruism kurang berkembang dalam lingkungan sekolah.

Comte (Taufik, 2012) mendefinisikan altruism berasal dari kata "alter" yang artinya "orang lain". Secara bahasa altruisme adalah perbuatan yang berorientasi pada kebaikan orang lain. Sedangkan menurut Sears dkk (1994) altruisme adalah tindakan suka rela yang dilakukan oleh seseorang atau sekelompok orang untuk menolong orang lain tanpa mengharapkan imbalan apapun (kecuali mungkin perasaan telah melakukan kebaikan). Salah satu media yang digunakan dalam pembelajaran adalah media film. Menurut Kustandi, dkk (2013:64) film merupakan "kumpulan gambar-gambar dalam frame". Media film merupakan bagian dari pembelajaran sehingga siswa lebih mudah untuk memahami materi yang di sampaikan melalui pemutaran film tersebut. Film juga bersifat edukatif yang mampu menghibur sehingga dapat dengan mudah menyampaikan materi kepada siswa secara baik. 
PSISULA: Prosiding Berkala Psikologi

Vol. 1, 2019

E-ISSN: 2715-002X

\section{Metode}

Penelitian dilaksanakan di SD Muhammadiyah 10 Balongbendo. Populasi dalam penelitian ini adalah seluruh siswa kelas $\mathrm{V}$ pada semester ganjil yang berjumlah 40 orang siswa. Sampel penelitian diambil sebanyak 2 kelas dengan rincian 1 kelas sebagai kelas eksperimen dan 1 kelas sebagai kelas control. Penelitian yang dilaksanakan menggunakan metode kuantitatif dalam bentuk kuasi eksperimen (Quasi Experimental Design). Bentuk disain kuasi eksperimen yang digunakan yakni Nonequivalent Control Group Design.

Dalam penelitian ini, media yang pembelajaran yang digunakan berupa media film motivasi yang dirancang disesuaikan kebutuhan kegiatan penelitian yakni membahas mengenai anak-anak sekolah yang mempunyai jiwa prososial yang tinggi. Film motivasi tersebut ditayangkan pada 2 jam pelajaran di kelas eksperimen yang berlangsung sebanyak 4 kali pertemuan.

Data yang dikumpulkan dalam penelitian ini berdasarkan fenomena yang ada di lingkungan sekolah. Teknik analisis data yang digunakan dalam penelitian ini adalah uji beda dengan menggunakan uji statistik non parametric yakni Uji Mann Whitney dan Wilcoxon.

\section{Hasil}

Pada kelas kontrol, rata-rata hasil pre test kelas kontrol sebesar 114,00 dengan standard deviasi sebesar 12,994. Dari 20 orang siswa pada kelas kontrol, skor terendah yang diraih adalah 87sebanyak 1 orang sedangkan skor tertinggi adalah 128 sebanyak 1 orang. Rata-rata hasil post test sebesar 110,95 dengan standard deviasi sebesar 14,937. Dari 20 orang siswa pada kelas kontrol, skor terendah yang diraih adalah 75 sebanyak 1 Orang sedangkan skor tertinggi adalah 134 sebanyak 1 orang. Setelah kegiatan pembelajaran dilakukan, secara umum terjadi peningkatan altruism siswa rata-rata sebesar $-3,05$. Meskipun demikian secara rinci terdapat penurunan di hasil altruism siswa pada 3 orang siswa, peningkatan altruisme siswa pada 13 orang siswa, dan yang tidak mengalami perubahan atas altruism siswa sebanyak 4 orang siswa. 
PSISULA: Prosiding Berkala Psikologi

Vol. 1, 2019

E-ISSN: 2715-002X

Pada kelas eksperimen, rata-rata hasil pre test sebesar 125,60 dengan standard deviasi sebesar 6,684. Dari 20 orang siswa pada kelas eksperimen, skor terendah yang diraih adalah 107 sebanyak 1 orang sedangkan skor tertinggi adalah 137 sebanyak 1 orang. Rata-rata hasil post test sebesar 126,10 dengan standard deviasi sebesar 10,447. Dari 20 orang siswa pada kelas eksperimen, skor terendah yang diraih adalah 106 sebanyak 1 orang sedangkan skor tertinggi adalah 148 sebanyak 1 orang. Setelah kegiatan pembelajaran dilakukan, secara umum terjadi peningkatan altruism siswa rata-rata sebesar 0,5. Meskipun demikian secara rinci terdapat penurunan di hasil altruism siswa pada 1 orang siswa, peningkatan altruism siswa pada 14 orang siswa, dan yang tidak mengalami perubahan atas altruism siswa sebanyak 5 orang siswa.

Nilai terendah pretest pada kelas eksperimen lebih baik dari kelas kontrol (107>87). Demikian pula dengan nilai tertinggi pre test kelas eksperimen lebih baik dari kelas kontrol (137>128). Nilai terendah post test pada kelas eksperimen lebh baik dari kelas kontrol (106>75). Sedangkan nilai tertinggi post test pada kelas eksperimen lebih baik dengan kelas kontrol (148>134).

Dilihat dari peningkatan altruisme, pada kelas eksperimen dan kelas control sama-sama terjadi peningkatan altrusme. Meskipun demikian, pada kelas eksperimen terjadi peningkatan yang lebih tinggi yakni sebesar 0,87 (tinggi) sedangkan pada kelas control hanya terjadi peningkatan sebesar 0,43 (sedang).

Pemgujian hipotesis menunjukkan bahwa : 1) tidak terdapat perbedaan signifikan hasil altruisme siswa antara kelas yang menggunakan dan tidak menggunakan media pembelajaran film jembatan pensil sebelum perlakuan (pre test) ; 2) terdapat perbedaan hasil altruisme siswa di kelas yang tidak menggunakan media pembelajaran film jembatan pensil sebelum dan sesudah perlakuan (pre test - post test) ; 3) terdapat perbedaan hasil altruisme siswa di kelas yang menggunakan media pembelajaran film jembatan pensil sebelum dan sesudah perlakuan (pre test - post test) ; 4) terdapat perbedaan signifikan hasil altruisme siswa antara kelas yang menggunakan dan tidak menggunakan media pembelajaran film jembatan pensil setelah perlakuan (post test), dan 5) terdapat perbedaan 
PSISULA: Prosiding Berkala Psikologi

Vol. 1, 2019

E-ISSN: 2715-002X

signifikan peningkatan (gain) hasil altruisme siswa antara kelas yang menggunakan dan tidak menggunakan media pembelajaran film jembatan pensil.

\section{Diskusi}

Hasil analisis data menunjukkan bahwa ada pengaruh penggunaan media film terhadap sikap altruisme.Altruis diartikan oleh Aronson, Wilson, \& Akert (dalam Taufik, 2012) sebagai pertolongan yang diberikan secara murni, tulus, tanpa mengharap balasan (manfaat) apa pun dari orang lain dan tidak memberikan manfaat apa pun untuk dirinya.

Senada dengan hal tersebut, David O. Sears mengartikan altruisme lebih jelas lagi yaitu sebagai tindakan yang dilakukan sesorang atau kelompok orang untuk menolong orang lain tanpa mengharap imbalan apapun, kecuali telah memberikan suatu kebaikan.

Pemanfaatan film Jembatan Pensil terutama ketika hal ini merupakan sesuatu yang belum pernah diterima siswa, tentu saja memberikan sebuah pengalaman bersosial yang baik dan baru. Yang lebih menyenangkan dan mampu menarik minat siswa untuk belajar sikap prososial dan berpartisipasi aktif dalam kegiatan pembelajaran altruisme yang berlangsung selama empat kali pertemuan tersebut.

Untuk penelitian terdahulu sama-sama menggunakan media film untuk menumbuhkan semangat siswa di dalam kelas. Peneliti tersebut menggunakan film animasi sedangkan saya menggunakan film motivasi "Jembatan Pensil". Pengamatan yang dilakukan selama kegiatan penelitian menunjukkan peningkatan minat dan motivasi belajar siswa untuk terlibat dalam kegiatan sosial yang berada di lingkungan sekolah. Dari hasil pengamatan, siswa menjadi lebih mudah dalam bergaul dengan teman sebayanya dan lebih perhatian dengan teman-teman yang ada di kelas.

Adanya sinyalemen positif yang terlihat dari peningkatan hasil altruisme dan juga meningkatnya motivasi altruisme siswa menunjukkan bahwa film Jembatan Pensil memang memiliki kelebihan-kelebihan yang terkait dengan optimalisasi 
PSISULA: Prosiding Berkala Psikologi

Vol. 1, 2019

E-ISSN: 2715-002X

peranan dan aktivitas siswa dalam kegiatan di lingkungan sekolah sebagaimana diuraikan oleh Kustandi, dkk (2013:64) film merupakan "kumpulan gambar-gambar dalam frame". Media film merupakan bagian dari pembelajaran sehingga siswa lebih mudah untuk memahami materi yang disampaikan melalui pemutaran film tersebut. Film juga bersifat edukatif yang mampu menghibur sehingga dapat dengan mudah menyampaikan materi kepada siswa secara baik.

\section{Kesimpulan}

Berdasarkan hasil penelitian dan pembahasan maka dapat ditarik kesimpulan sebagai berikut:

1. Tidak terdapat perbedaan signifikan hasil altruisme siswa antara kelas yang menggunakan dan tidak menggunakan media pembelajaran film jembatan pensil sebelum perlakuan (pre test).

2. Terdapat perbedaan hasil altruisme siswa di kelas yang tidak menggunakan media pembelajaran film jembatan pensil sebelum dan sesudah perlakuan (pre test - post test).

3. Terdapat perbedaan hasil altruisme siswa di kelas yang menggunakan media pembelajaran film jembatan pensil sebelum dan sesudah perlakuan (pre test post test).

4. Terdapat perbedaan signifikan hasil altruisme siswa antara kelas yang menggunakan dan tidak menggunakan media pembelajaran film jembatan pensil setelah perlakuan (post test) dan terdapat perbedaan signifikan peningkatan (gain) hasil altruisme siswa antara kelas yang menggunakan dan tidak menggunakan media pembelajaran film jembatan pensil. 
PSISULA: Prosiding Berkala Psikologi

Vol. 1, 2019

E-ISSN: 2715-002X

\section{Daftar Pustaka}

Arikunto Suharsimi. (2006). Prosedur Penelitian Suatu Pendekatan Praktik Edisi Revisi VI. Jakarta: Asdi mahasatya.

Dayakisni, T., \& Hudaniah. (2003). Psikologi Sosial. Malang: UMM Press.

Gunarsa, S. (2000). Psikologi Perkembangan Anak dan Remaja. Jakarta: BKK Gunung Mulia.

Gusti, A. Y., \& Margaretha P. M. (2010). Perilaku Prososial Ditinjau dari Empati dan Kematangan Emosi. Jurnal Psikologi. 9(3): 56-78.

Hadari Nawawi. (2015). Metode Penelitian Bidang Sosial. Yogyakarta. Gadjah Mada University Perss.

Hegarty, Mary. (2004). Commentary dynamic visualizations and learning: getting to the difficult questions. Learning and Instruction. 14, 343-351.

Jarolimek, John. Parker, Walter C. (1993). Social Studies In Elementary Education: Ninth Edition. New York: Macmillan Publishing Company.Marsh, Collin. (1987). Teaching Social Studies. Australia: Prentice Hall.

Magdalena. (2012). Pengaruh Empati terhadap Perilaku Altruisme sesama Pengendara Sepeda Motor. Jurnal Psikologi, 2(7): 120-144.

Sugiyono.(2006). Metode Penelitian Administrasi. Bandung. CV. Alfabeta. (2016). Metode Penelitian Pendidikan: PendekatanKuantitatif, Kualitatif, dan $R \& D$. Bandung. Alfabeta . 